\title{
A REALITY CHECK: THE CHALLENGES OF IMPLEMENTING INFORMATION POWER IN SCHOOL LIBRARY MEDIA PROGRAMS
}

\author{
Cheryl Ann McCarthy \\ Graduate School of Library and Information Studies \\ University of Rhode Island \\ Rodman Hall, Kingston, RI 02881-0815 USA \\ E-mail: chermc@uriacc.uri.edu.us
}

\begin{abstract}
How well are school library media programs realizing the mission, objectives and challenges set by Information Power? Teacher-librarians are struggling to realize its ideals in less than ideal circumstances. To gain a broader understanding of their work and success, this paper studies 48 good library media programs in New England Region, U.S. using a combination of qualitative and quantitative methods to ensure the perceived success of participating programs in conforming to the national guidelines.
\end{abstract}

\section{INTRODUCTION}

The American Association of School Librarians (AASL) and the Association for Educational Communication and Technology (AECT) are reconsidering the national (U.S.) guidelines, Information Power (1988). A joint Committee revising the guidelines has chosen to focus on a new vision for the future-learning-centered libraries. The vision will stress learning and the learning community of the whole school, not in isolation, but by emphasizing the roles of the library media specialist in relation to the learning community. School library media specialists will be challenged to weave partnerships, exercise leadership, and advocate for student achievement and information literacy standards appropriate for all areas (Stripling, 1996). Before articulating a new vision, however, one needs first to assess whether school library media programs are presently realizing the mission, goals, and objectives set by Information Power. If library media specialists are to be challenged to assume additional responsibilities and roles, the question needs to be asked whether they are fulfilling the current roles of teacher, information specialist, and instructional consultant.

Information Power has posed many challenges for school library media specialists who struggle to realize its ideals in less than ideal circumstances. In performing a reality check on Information Power, one needs to address the following questions: Can the goals of Information Power be realized in the current culture of schools? How effective have library media specialists been in negotiating change and translating the mission into realizable programs? Have programs become fully staffed and flexibly scheduled? How well are information literacy skills and instructional technology integrated into the whole curriculum? Are library media budgets adequate to support effective programs?

This investigation sets out to answer these questions by assessing the current status of fortyeight library media programs in the New England region (Rhode Island, Massachusetts, Connecticut, New Hampshire, and Maine) of the United States through a comparison and analysis of data, and through drawing inferences. To gain a broader understanding of how well library media specialists translate the mission of Information Power into reality, the investigator analyzed data on forty-eight library media programs within their existing school cultures. The methods used were personal observations and a survey of library media specialists and student library media specialist interns. 
Recommendations and future implications are then offered to help create fully integrated library media programs for the Twenty-first Century where students will achieve information literacy.

\section{THE CULTURE OF SCHOOLS AND EDUCATION REFORM}

The culture of schools and library media programs interest this investigator as both a researcher and a professional concerned with support for library media programs centered on student learning. In 1992-1993 a task force of library media specialists including this investigator from the Rhode Island Educational Media Association, wrote student learning goals for mastery of information literacy skills in library media programs. Although these goals were praised as exemplary and desirable by Rhode Island's Commissioner of Elementary and Secondary Education, they have not been formally adopted as state standards. Other New England states have also written meaningful goals or standards for their library media programs, but none have been mandated or adopted as state standards. In the absence of National or State standards requiring fully staffed and flexibly scheduled learning-centered programs, the responsibility for leadership and implementation of these goals has been left to the individual library media specialist.

Therefore, it seems that the culture-or learning climate-of the school and how well the library media specialist negotiates his/her roles, has determined the success of each program. Success varies widely depending on the culture of reform in the school and depending on whether a full-time library media specialist exists, has an adequate budget, a variety of resources and technology, and an integrated program of services. Since the (U.S.) National Commission on Excellence in Education [NCEE] issued its report, A Nation at Risk, (1983) schools have responded to its charge that the United States country's education system is "a rising tide of mediocrity that threatens our very future as a nation and a people." (p. 5) In addition, the report asserts that the failure of the education system is threatening the United States' world leadership, our economic competitiveness, and democracy, all of which depend on an educated and literate society. The Commission further called for education reform in both the quantity and quality of curricular content and instruction. The Commission hoped that their report would raise standards and expectations of the nation's educational system as well as improve the quality of teaching and learning (NCEE, 1983).

What have these reform efforts produced? The National Center for Education Statistics (NCES) reports that although high school students are taking more core courses and more rigorous and advanced placement courses, achievement rates have increased only slightly in math and science and have decreased in reading from 1982 to 1992 as measured by the National Assessment of Educational Progress (Smith, 1995). Although statistics indicate that schools have made some curricular improvements, little substantive or systemic change has occurred nationwide. Continued cries for reform tend to center on the need for national standards, assessments, and accountability (Gagnon, 1995; Daedalus, 1996; Fiske, 1992). President Clinton has also called for education reform as the top priority in his State of the Union Address in January 1997.

One example of a successful reform movement seems to be the Coalition of Essential Schools. Theodore Sizer, University Professor Emeritus at Brown University and founding director of the Annenberg Institute for School Reform is Chairman of the Coalition of Essential Schools. He claims that most of the "systemic reform" efforts nationwide have produced little substance; rather, they only served to streamline the education hierarchy and to legislate vague reforms, such as Goals 2000 (1996, pp. 47-48). Instead, he believes that schools should be developing thoughtful intellectual habits to help students learn to use their minds well. Some of the Coalition's reform efforts are not new. Sizer admittedly acknowledges John Dewey as the forerunner of some of the Coalition's ideas (Sizer, 1992). In his latest book, Horace's Hope, Sizer (1996) is confident that meaningful reform is occurring in Coalition of Essential Schools where young people demonstrate their mastery of essential skills and areas of knowledge through exhibitions.

How have school library media programs responded to the call for reform? In recognition of the need to integrate school library media programs into the curriculum of the whole school, AASL and AECT (1988) adopted national guidelines, Information Power, calling for a shift in emphasis from media collections to integrated instructional technologies and information skills in the curriculum. Information Power defines the library media specialist's mission as ensuring "that students and staff are effective users of ideas and information." (p. 1) To fulfill this mission, library media specialists are called to perform all three roles of teacher, information specialist, and 
instructional consultant (pp. 38-39). Library media specialists, however, cannot do it alone. They need partnerships with teachers, administrators, unions, and parents in order to collaborate and to negotiate change in the school culture. Perhaps, library media programs can learn from the success of the Coalition's reform efforts by defining information literacy skills as essential. In addition, information literacy skills need to be adopted as National Standards and integrated throughout the curriculum. Furthermore, library media specialists need a framework for both teaching and assessing students' mastery of information literacy skills and to become accountable for student achievement.

How does one determine whether library media programs are succeeding in translating the mission of Information Power into reality? One needs to measure whether programs are meeting the stated requirements, objectives and challenges as outlined in Information Power. The most common method of studying school library media programs remains the questionnaire (Grover \& Fowler, 1992). Although anthropologists have been conducting ethnographic studies of schools and their cultures since the late 1940s, there have been few such studies of school libraries (Mellon, 1990; Spindler, 1982). Although a survey can measure a program's perceived effectiveness, only observation can confirm this perception. Thus, this study assesses forty-eight school library media programs within the culture of their schools using both qualitative means (unobtrusive observations with content analysis) and quantitative means (a questionnaire with statistical analysis).

Like other philosophical calls for education reform in the 1980s, Information Power is research-based. It defines the mission of the library media program as ensuring "that students and staff are effective users of ideas and information" To fulfill this mission, three factors are required in the culture of the school to create effective programs:

1. full integration of the library media program into the curriculum

2. a partnership among the library media specialist, district-level personnel, administrators, teachers, and parents,

3. the serious commitment of each of those partners to the value of universal and unrestricted access to information and ideas

In addition, seven objectives are identified:

1. to provide intellectual access to information;

2. to provide physical access to information;

3. to provide learning experiences that encourage users to become discriminating consumers and skilled creators of information;

4. to provide leadership, instruction, and consulting assistance;

5. to provide resources and activities that contribute to lifelong learning;

6. to provide a facility that functions as the information center of the school;

7. to provide resources and learning activities that represent a diversity of experiences, opinions, social and cultural perspectives. (AASL \& AECT, 1988, pp. 1-2).

Information Power also identifies five challenges faced by library media specialists in reshaping their programs to fulfill these guidelines:

1. To provide intellectual and physical access to information and ideas for a diverse population whose needs are changing rapidly

2. To ensure equity and freedom of access to information and ideas, unimpeded by social, cultural, economic, geographic, or technological constraints

3 . To promote literacy and enjoyment of reading, viewing, and listening for young people at all ages and stages of development

4. To provide leadership and expertise in the use of information and instructional technologies

5. To participate in networks that enhance access to resources located outside the school. (AASL \& AECT, 1988, pp. 3-12) 
Research has shown that only when it is possible for librarian and teacher to collaborate can the library media program's full benefits be realized for student learning (Eaton \& McCarthy, 1995; Giorgis \& Peterson, 1996; Haycock, 1992; Putnam, 1996; Shannon, 1996). Such collaboration, however, does not come easily. Joint planning takes time, and according to Diane Oberg (1990), it may also involve "negotiating a change in the cultural norms of [the] school, from privacy and selfreliance to collegiality and experimentation." (p. 9) Moreover, in the only study that has recently measured the impact of school library media centers on academic achievement, Keith Curry Lance has shown that well equipped library media centers make a difference. In the Colorado study, Lance (1993) identified the most significant factor on student academic achievement as a well stocked library media program with a library media specialist providing access and a program of services.

This investigation does not attempt to evaluate individual schools or programs, but to assesses the effectiveness of library media programs in implementing Information Power. The school culture, the climate of reform, and student achievement influence the opportunities for collaboration and change in library media programs. The realistic opportunities as well as the barriers to change are identified in this study from observations by the investigator and from the responses to the questionnaire by library media specialists and student library media specialist interns. Thus, for each site there are three different perspectives offering a well rounded view of the library media program within the context of the school.

\section{THE CONTEXT-THE SCHOOLS}

The forty-eight schools in this study were initially selected by student interns for their 300 hour practicum field experiences in the Spring of 1994 and 1995. Most sites were selected from a database of approximately 200 good school library media programs throughout New England where media specialists have volunteered to serve as mentors in the past five years. The sites are recommended as exemplary, not because they are ideal, but because good people are striving to provide effective programs. They represent all levels: elementary, middle and high schools. The practicum students in this study chose two good schools within commuting distance from their homes where good library media specialists are willing to act as mentors allowing them to share in their programs. In addition, the library media specialists in this study voluntarily agreed to cooperate with the Coordinator of the School Library Media Program, the investigator, by completing the survey under the condition of anonymity.

At the University of Rhode Island's Graduate School of Library and Information Studies, the Coordinator of the School Library Media Program is committed to teach the principles of Information Power and to place student interns in schools where mentors are striving to fulfill the mission of Information Power. One of the program's requirements is a nine credit-hour practicum and seminar. The practicum requires students to work as interns for 300 hours at two sites (150 hours or five weeks at an elementary school and 150 hours or five weeks at a middle or secondary school). Each student is required in the Fall semester to do observations, interviews, and requests for placement at two sites either from the database of recommended sites or additional sites they have observed. These schools represent exemplary programs where practitioners have high professional standards and serve as capable mentors. In addition, each student must demonstrate thirty competencies by fulfilling all three roles of the library media specialist: teacher, information specialist, and instructional consultant. The coordinator routinely visits each site to observe the student's progress and growth. Thus as both the coordinator and the investigator of this study, visits to the practicum sites also provided opportunities for unobtrusive observations. All sites and individuals will remain anonymous and are treated in the aggregate.

While all the library media specialists expressed a commitment to the principles of Information Power, the opportunities for implementation as well as collaborations with teachers differed widely. Some schools have many advantages: creative and enthusiastic full-time library media specialist, library media support staff, a flexible schedule, opportunities to collaborate with teachers, and supportive administrators, teachers, parents, and students. Other schools have few advantages: an enthusiastic but part-time library media specialist covering several schools, no library media support staff, a rigid schedule of classes, few opportunities to collaborate with teachers, and less supportive administrators, teachers, parents, and students. 
Library media specialists without flexible schedules have little time to work with teachers and less opportunity to plan integrated activities for student learning. Moreover, Eleonor Putnam's research (1996) supports earlier studies revealing that while library media specialists perceive their role of instructional consultant as important, practice is lagging in fixed schedule programs. Putnam's results confirm that "Flexible schedule programs can provide a better vehicle to achieving a welldeveloped library media program." (p. 47) Putnam concludes that, "For Information Power to be more widely implemented in the schools, more library media specialists must work within a flexible schedule program." (p. 48) In this study the roles of the library media specialist vary from school to school as does the learning climate, even though the library media specialists are aware of the importance of all three roles. Despite the enthusiasm of the library media specialists, conditions for implementing Information Power are not necessarily equitable or optimum in each school.

Factors which appear to be disadvantages-for instance, budgetary and scheduling constraints-are useful in this study to help identify barriers to implementing Information Power programs. While all high schools in this study have flexibly scheduled programs, most elementary schools do not. Financial limitations into the 1990s are typical both in New England and nationwide, especially in elementary programs (DeCandido \& Mahony, 1992; White, 1990) and since the end of the Elementary and Secondary Education Act (ESEA Title IV) funds (McCarthy, 1993). Recognizing that not all sites are ideal, this study focuses on what happens when good people try to move towards the ideal, but must adapt to what is possible given the school culture (Eaton \& McCarthy, 1995).

\section{FIELDWORK METHODOLOGY}

\section{Objectives}

The objectives for this study are:

1. To analyze to what extent library media programs are able to meet the mission, requirements, objectives, and challenges of Information Power,

2. To assess the realistic opportunities and barriers library media specialists face in translating the mission of Information Power into realizable programs, and

3. To identify how library media programs are influenced by the culture of the school.

\section{Quantitative Methods}

To measure these objectives, the investigator used a combination of methods. She designed, pretested, and revised a survey instrument eliminating any ambiguity in language. The survey questions are straightforward and ask to what extent library media programs fulfill specific elements of Information Power. Thus, the survey instrument is valid by measuring what was intended. The investigator used forty-eight sites with voluntary participation of library media specialists and student interns. A total of one hundred and four respondents completed the questionnaire with forty-eight library media specialists and fifty-six students from the forty-eight practicum sites. Eight additional student responses represent interns who completed their practicum at sites that were also participating in this study. The library media specialists at these sites, however, were not asked to complete a duplicate survey, nor were their scores duplicated. Thus, the responses were not paired, but averaged to obtain mean scores for each question. Responses from library media specialists and student interns provide a check on reliability.

Quantitative responses using a Likert-type scale for forced-choice questions (1-15) were tabulated and tables were prepared to compare means and standard deviations of mentor and student responses as well as to measure the perceived success of library media programs to conform to the national guidelines. The following elements from Information Power were measured: the three required factors (questions 1-3), the seven objectives (questions 4-10), and the five challenges (questions 11-15).

\section{Qualitative Methods}

To assess further the objectives, qualitative methods were used to evaluate the influence of the school culture on the library media program. During the coordinator's routine observations of the students' progress at the practicum sites, she observed the ongoing activities, programs, and school culture. By a school culture, one implies the learning climate, including shared beliefs, customs, 
expectations, and practices of teachers, administrators, library media specialists, parents and students. Using unobtrusive observations of programs as well as discussions with library media specialists and student interns, the coordinator gleaned insights into the whole learning community. The investigator applied content analysis to the recorded observations, identifying subject categories focusing on the library media program within the school culture.

In addition, survey questions 16-20 were open-ended asking library media specialists and student interns whether they believe the mission is realizable in their schools and how the school culture, including schedule, attitudes, and technology influence their programs. Content analysis of open-ended questions allowed the investigator to identify and rank-order both positive and negative factors that influence library media programs. The students' and the library media specialists' explanations for the open-ended questions were similar or the same; thus, the rationales of both were coded into categories, combined, and rank-ordered in questions $16-20$.

The investigator was thus able to gain a full insight into the data and to make inferences about the schools' programs from the perspectives of the library media specialists, the student interns, and the coordinator. The combination of both quantitative and qualitative data yields a solid foundation for grounded theory on the effectiveness of school library media programs and the factors governing implementation of Information Power in schools in the New England region. While this data cannot be generalized to the whole country, the results do confirm studies done in other geographic areas as well (Putnam, 1996; Shannon, 1996).

\section{RESULTS: INTERPRETATION OF DATA}

\section{Information Power}

When asked in question 16 whether the mission, objectives, and challenges of Information Power are fully realizable at your school, 42 percent of the library media specialists and 48 percent of the students indicated "yes." Library media specialists appear less optimistic with 58 percent of the library media specialists as opposed to 52 percent of the students indicating that Information Power cannot be realized or only somewhat realized (see Table 1).

\section{TABLE 1}

QUESTION 16: Do you believe that the mission, objectives, and challenges of Information Power are realizable at your school?

\begin{tabular}{lccrccccc}
\hline & YES & $\%$ & $\begin{array}{c}\text { SOME- } \\
\text { WHAT }\end{array}$ & & NO & $\%$ & ROW & ROW \% \\
LMS Responses & 20 & 41.7 & 13 & 27.0 & 15 & 31.3 & 48 & $100 \%$ \\
Student Responses & 27 & 48.2 & 15 & 26.8 & 14 & 25.0 & 56 & $100 \%$ \\
COLUMN TOTAL & 47 & 45.2 & 28 & 26.9 & 29 & 27.9 & 104 & $100 \%$ \\
\hline
\end{tabular}


Both students and practitioners offered the same reasons; so their open-ended explanations were coded and rank-ordered together into either positive or negative factors. The negative factors (or barriers) prohibiting the realization of Information Power were identified as:

- Lack of support for budget, resources, technology, and staff;

- Lack of a flexible schedule to allow for collaboration;

- Lack of support and commitment from school committees, administrators, unions and

teachers reluctant to change;

- Lack of an educational philosophy or vision supportive of Information Power; and

- Inability to fulfill the instructional consultant role.

The positive factors (or opportunities) supporting the realization of Information Power were identified as:

- Strong library media specialist committed to reaching out to teachers and providing a

high

quality program;

- Support from administration and teachers;

- Collaboration with teachers and the use of the library media center by teachers;

- Support for budget and resources by administration; and

- An educational philosophy or climate conducive for students to use information

resources wisely and to appreciate literature.

Ironically, the reasons given as negative factors are similar to those given as positive factors for the implementation of Information Power. The number one element identified as necessary to fulfill the mission is a professional library media specialist committed to provide a high quality program. Both practitioners and students recognized that it is the individual who creates effective programs, but without support cannot fulfill the mission alone. Support is needed from administrators (for budget, scheduling, staff, resources, and technology) and from teachers (for collaboration and integration). Thus, without change, Information Power will remain an ideal, not a reality for the majority of library media programs in New England.

\section{Staff and Schedule}

Are programs fully staffed and flexibly scheduled? Yes, if it is a high school or a middle school program. High schools and middle schools have full-time library media specialists and most had at least a full-time assistant for clerical or technical support. The elementary programs, however, are not flexibly scheduled and lack support staff. Only one elementary program has a full-time library media specialist with a full-time assistant. According to the demographics, most elementary library media specialists cover more than one school with little or no support staff. While all high schools have flexible schedules and middle schools have either flexible or modified flexible schedules, most elementary schools have fixed schedules with assigned classes. Although elementary and secondary programs were identified, all library media specialists' responses were combined and all practicum students' responses were combined when creating tables for frequency counts and percentage for questions 16, 17, and 19. Table 2 shows almost 50 percent of the schools have fixed schedules with assigned classes while slightly more than 50 percent have a flexible schedule (see Table 2). This correlates to an approximately equal division of elementary with fixed schedules and secondary with middle or high school programs with flexible schedules. The eight middle schools in this study were counted as secondary programs because of their flexible or modified- flexible schedule.

When media specialists were asked in question 17 to explain their schedule, program, and use of their library media centers, 50 percent identified positive elements, while the other 50 percent identified negative elements. The type of schedule appears to be the determining factor in how library media specialists view their programs. Those library media specialists with flexible schedules identified the best feature of their program as the integration with the curriculum because of cooperative planning with teachers and meaningful assignments for students. Most respondents with flexible schedules also observed greater faculty and student use because teachers who used the facility were more apt to create research 
TABLE 2

QUESTION 17: Does your library media program have an open and flexible schedule?

\begin{tabular}{lcccccccc}
\hline & YES & $\%$ & $\begin{array}{c}\text { SOME- } \\
\text { WHAT }\end{array}$ & $\%$ & NO & $\%$ & $\begin{array}{c}\text { ROW } \\
\text { TOTAL }\end{array}$ & ROW \% \\
LMS Responses & 25 & 52.1 & 7 & 14.6 & 16 & 33.3 & 48 & $100 \%$ \\
Student Responses & 29 & 51.8 & 7 & 12.5 & 20 & 35.7 & 56 & $100 \%$ \\
COLUMN TOTAL & 54 & 51.9 & 14 & 13.5 & 36 & 34.6 & 104 & $100 \%$ \\
\hline
\end{tabular}

assignments to encourage student use. According to the respondents, the students in these schools viewed the library media center as the place of choice to do research and assignments. Two high school library media specialists, however, complained that their students viewed the library as an optional study hall because that has become its primary function. One respondent lamented that the use of the library media center as a study hall has limited teachers' use and limited media services that could be provided. The library media specialist commented further that the principal views the library as a "privilege for study hall students." The student intern at this site confirmed that the library media specialist is so busy supervising study hall students, that the "program is practically nonexistent." The investigator believes that the diminished expectations by the principal and teachers, as well as the lack of initiative by the library media specialist, has hindered the development of a program of services integrated with the curriculum.

Elementary library media specialists, on the other hand, reported that their fixed schedules create the following barriers that hinder their programs:

- library classes taught in isolation impede student achievement;

- lack of open time in the schedule inhibits planning with teachers;

- and lack of an integrated program hinders curriculum development.

With a fixed schedule of approximately five assigned classes per day, the elementary school library media specialists lamented that they are often viewed as "preparation or unassigned time" by teachers who have a free period during library time. Furthermore, without time to collaborate with teachers, elementary library media specialists seem limited to teaching skills in isolation or to reading stories and then to providing circulation time. When these assigned classes are in session, in some schools students do not have access to the library media resources since there is no additional staff to service them. One library media specialist stated that "library class" is viewed by teachers as enrichment or "literature appreciation," but not "real learning" because "real learning is what goes on in the classroom." Although library media specialists desire to fulfill the instructional consultant role, the elementary school schedule does not allow time to collaborate with teachers. Therefore, collaboration and team teaching with teachers was practically non-existent for most elementary programs on a fixed schedule, except for some limited opportunities. For the most part, connections with the curriculum took place when the library media specialist was flexible and coordinated plans with a classroom theme or topic in an informal activity.

\section{Informational and Instructional Technology}

How well have informational and instructional technologies been integrated into the whole curriculum? Not well according to most respondents when asked in question 19 to describe their instructional technology programs. Most library media specialists participating in this study do not even have automated systems for circulation and online catalog. Only one-third or sixteen of the forty-eight schools have automated systems including fourteen secondary schools and two elementary schools. Six respondents indicated that they were either in process of planning for automation or converting their partial record circulation system to a full MARC record catalog system or were writing grants to prepare for automation. Twenty-six schools have no automation plans or no funds for automation (see Table 3). 
The determining factor in creating instructional technology programs was whether there was a budget for technology. Two-thirds of the respondents did not have any budget for technology. The

TABLE 3

QUESTION 19: Do you have an automated system, circulation and catalog?

\begin{tabular}{lrrrrrrrr}
\hline & YES & $\%$ & $\begin{array}{c}\text { SOME- } \\
\text { WHAT }\end{array}$ & & NO & $\%$ & $\begin{array}{c}\text { ROW } \\
\text { TOTAL }\end{array}$ & ROW \% \\
LMS Responses & 16 & 33.3 & 6 & 12.5 & 26 & 54.2 & 48 & $100 \%$ \\
Student Responses & 17 & 30.3 & 9 & 16.1 & 30 & 53.6 & 56 & $100 \%$ \\
COLUMN TOTAL & 33 & 31.7 & 15 & 14.4 & 56 & 53.9 & 104 & $100 \%$ \\
\hline
\end{tabular}

comments describing technology programs in question 19 were coded and rank-ordered into either negative factors or positive factors. Many library media specialists lamented that there was no technology in their facilities because there was "no budget" for technology. Some commented that the technology budget was centralized in the district or an administrator or "tech-ed teacher" had responsibility for the technology budget. In those schools the person with budgetary authority for technology did not seem to share the vision of the library media center as the hub of informational and instructional technology. A few schools did not even have unified library media programs because audio-visual and instructional technologies were located elsewhere, either centralized in the district or in other departments.

The widest discrepancy in technology programs appears between high school programs that were automated and had technology and elementary programs that were not automated and had little or no technology. There seems to be a lack of vision and planning for informational and instructional technologies in some library media programs, especially elementary schools where print budgets also are severely limited. In this study most schools did not have a system-wide K-12 technology plan in 1994 and 1995, although a few were beginning the process of creating one. It seems imperative to this observer that library media specialist need to take a leadership role in the planning process or they will be left behind. Some library media specialists, especially in elementary programs, were understandably reluctant to assume more responsibility for technology, citing as reasons: lack of time in a fixed schedule, lack of technical knowledge and lack of technology support staff.

Library media specialists identified the major advantage of technology in their programs as providing better access to resources and information for students and teachers. The most frequently cited technology resources for high school and middle school programs include the following: an online catalog; CD-ROM databases, such as SIRS, Infotrac, electronic encyclopedias, Readers' Guide, and Newsbank; an Internet connection; and a networked computer lab. Although some schools had Internet connections, most were limited to one computer and none had yet formulated policies for student access. (Since completion of this survey, many districts have adopted a Technology Plan K12 and some now have Acceptable Use Guidelines or Policies for responsible use of the Internet by students.)

\section{Budgets}

Are library media budgets adequate to support effective programs? For the most part, "no," according to forty-six library media specialists who provided data on their budgets. The survey asked for a breakdown of budget figures for "print," "a-v," "technology," and "supplies." A chart was created from the data to identify the range of budget figures and the averages. While the range of the print budget was from $\$ 0$ to $\$ 17,000$, the mean print budget was $\$ 5,390$. The average audio-visual ("a-v") budget was $\$ 1,338$. The average technology budget was $\$ 734$; however, if the thirty-two sites with zero budgets for technology are eliminated from the data, then the mean budget for sixteen schools is $\$ 2,203$. With a budget average of $\$ 2,203$ each of the sixteen schools could purchase 
approximately one computer. Therefore, library media specialists commented that budgets for technology were non-existent or inadequate. The average supplies budget was $\$ 461$. One person commented that the library media budget had been cut 50 percent for that fiscal year. The budgets for library media centers in Rhode Island reflect the decrease in overall budgets for Rhode Island schools in the 1990s due to a decrease in state aid to the local districts. Massachusetts and other New England states have also reported level funding of school budgets with level funding or decreases in library media center budgets.

It is not surprising that high school budgets are about four times higher than the elementary school budgets. In one school district an elementary school budget was $\$ 1,700$ while the high school budget was ten times higher at $\$ 17,000$. Some school districts appropriate funds based on a per-pupil cost and high schools receive a larger allocation because of their larger populations. A few high school library media specialists admitted that their budgets increased by as much as $\$ 10,000$ in preparation for the New England Association of Secondary Schools and Colleges (NEASC) accreditation process. Elementary schools are not accredited by NEASC and thus do not benefit financially from this process. Some media specialists stated that their districts give one line-item budget for all library resources which was reported under print. Some schools allocate the a-v budget to individual departments or a centralized office, rather than to the library media centers. The budget item lacking for most programs was identified as "technology." For most schools in this study, it is evident that budgets are not meeting the high service programs in elementary or secondary programs as reported in Information Power, although these are good sites in New England (AASL \& AECT, 1988, Appendix A).

\section{School Culture and Information Power: A Reality}

How have library media specialists succeeded in negotiating change and translating the mission into realizable programs in their schools? Although library media specialists in this study are strongly committed to the mission and objectives set in Information Power, no library media program in this study has fully implemented all these guidelines yet. Frequency counts and mean scores were tabulated for each of the Likert-type scale for forced-choice questions. The investigator used the following numerical code to calculate each response:

$$
\begin{aligned}
& 1=\text { not yet } \\
& 2=\text { somewhat } \\
& 3=\text { frequently } \\
& 4=\text { fully. }
\end{aligned}
$$

Questions 1-3 asked whether their school met the three required factors: (1) Full integration into the curriculum, (2) Partnerships with library media specialist and others, and (3) Commitment to access. The library media specialists' mean score for required factors was 2.51 (somewhat) and the student interns' mean score was 2.53 for the required factors 1-3 (see Table 4).

Questions 4-10 asked to what extent their program was able to meet the seven objectives of Information Power: (4) Intellectual access; (5) Physical access; (6) Learning experiences; (7) Leadership in instructional technology; (8) Resources and activities for lifelong learning; (9) Facility as information center; (10) Resources and learning activities for diversity. The library media specialists' mean score for the seven objectives was 3.07 (frequently) and the students' mean score was 3.00 (frequently) (see Table 5). 


\section{TABLE 4}

\section{Comparison of Library Media Specialists' (LMS) and Students' Perceptions of Required Factors}

Questions 1-3: Information Power requires three factors that must be present to achieve the national mission. To what extent does your school support these factors?

Likert-type Scale (Choices and Code): Not Yet $=1$; Somewhat $=2 ;$ Frequently $=3$; Fully $=4$

\begin{tabular}{llllll}
\hline $\begin{array}{l}\text { Question \# and Abbreviated } \\
\text { Statement }\end{array}$ & $\begin{array}{l}\text { LMS } \\
\text { Responses } \\
\text { (mean) }\end{array}$ & $\begin{array}{l}\text { LMS } \\
\text { Standard } \\
\text { Deviation }\end{array}$ & $\begin{array}{l}\text { Student } \\
\text { Responses } \\
\text { (mean) }\end{array}$ & $\begin{array}{l}\text { Student } \\
\text { Standard } \\
\text { Deviation }\end{array}$ & $\begin{array}{l}\text { Mean } \\
\text { Difference }\end{array}$ \\
\hline \#1: Full integration into & 2.60 & .869 & 2.45 & .851 & .15 \\
$\quad \begin{array}{l}\text { Curriculum... } \\
\text { \#2: Partnerships with }\end{array}$ & 2.44 & .848 & 2.54 & .808 & -.10 \\
$\quad \begin{array}{l}\text { LMS and others... } \\
\text { \#3: Commitment to }\end{array}$ & 2.48 & 1.01 & 2.59 & .987 & -.11 \\
$\quad$ access... & & & & &
\end{tabular}

TABLE 5

\section{Comparison of Library Media Specialists' (LMS) and Students' Perceptions of Seven Objectives}

Questions 4-10: To what extent are you able to meet the following seven objectives?

Likert-type Scale (Choices and Code): Not Yet $=1$; Somewhat $=2$; Frequently $=3$; Fully $=4$

\begin{tabular}{|c|c|c|c|c|c|}
\hline $\begin{array}{l}\text { Question \# and Abbreviated } \\
\text { Statement }\end{array}$ & $\begin{array}{l}\text { LMS } \\
\text { Responses } \\
\text { (mean) }\end{array}$ & $\begin{array}{l}\text { LMS } \\
\text { Standard } \\
\text { Deviation }\end{array}$ & $\begin{array}{l}\text { Student } \\
\text { Responses } \\
\text { (mean) }\end{array}$ & $\begin{array}{l}\text { Student } \\
\text { Standard } \\
\text { Deviation }\end{array}$ & $\begin{array}{l}\text { Mean } \\
\text { Difference }\end{array}$ \\
\hline \#4: Intellectual access... & 2.96 & .743 & 3.04 & .785 & -.08 \\
\hline \#5: Physical access... & 3.42 & .647 & 3.31 & .69 & .11 \\
\hline \#6: Learning experiences... & 2.92 & .647 & 2.89 & .679 & .03 \\
\hline $\begin{array}{l}\text { \#7: Leadership in instructional } \\
\text { technology... }\end{array}$ & 2.90 & .778 & 2.86 & .962 & .04 \\
\hline $\begin{array}{l}\text { \#8: Resources and activities } \\
\text { for lifelong learning... }\end{array}$ & 3.10 & .627 & 2.93 & .684 & .17 \\
\hline $\begin{array}{l}\text { \#9: Facility as information } \\
\text { center }\end{array}$ & 3.10 & .692 & 3.09 & .793 & .01 \\
\hline 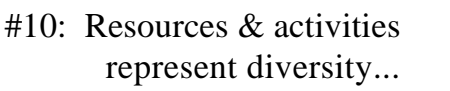 & 3.09 & .751 & 2.89 & .824 & .20 \\
\hline
\end{tabular}


Questions 11-15 asked to what extent their program was able to meet the five challenges to fulfill the mission: (11) Access/Diversity, (12) Equity and freedom of access, (13) Promote literacy and reading, (14) Leadership in information and instructional technologies, (15) Networks to enhance access. The library media specialists' mean score for the five challenges was 2.84 (somewhat) and the students' mean score was 2.83 (somewhat) (see Table 6). The overall mean score for questions 1-15 for library media specialists was 2.80 (somewhat) and the overall mean score for students was 2.78 (somewhat). Tables 4,5 , and 6 reveal both the mean scores for each question as perceived by both the library media specialists and the student interns as well as the standard deviations and difference between the means. The perceived levels of program fulfillment by the library media specialists and student interns appear comparable and reliable. These perceptions also appear valid and reliable to the investigator after observing each school.

\section{TABLE 6}

\section{Comparison of Library Media Specialists' (LMS) and Students' Perceptions of Challenges}

Questions 11-16: Information Power identifies five challenges to fulfill the mission. To what extent are you able to meet these challenges?

Likert-type Scale (Choices and Code): Not Yet $=1$; Somewhat $=2$; Frequently $=3$; Fully $=4$

\begin{tabular}{|c|c|c|c|c|c|}
\hline $\begin{array}{l}\text { Question \# and Abbreviated } \\
\text { Statement }\end{array}$ & $\begin{array}{l}\text { LMS } \\
\text { Responses } \\
\text { (mean) }\end{array}$ & $\begin{array}{l}\text { LMS } \\
\text { Standard } \\
\text { Deviation }\end{array}$ & $\begin{array}{l}\text { Student } \\
\text { Responses } \\
\text { (mean) }\end{array}$ & $\begin{array}{l}\text { Student } \\
\text { Standard } \\
\text { Deviation }\end{array}$ & $\begin{array}{l}\text { Mean } \\
\text { Difference }\end{array}$ \\
\hline \#11: Access/Diversity & 2.89 & 679 & 2.84 & .757 & .05 \\
\hline $\begin{array}{c}\# 12 \text { : Equity and freedom } \\
\text { of access... }\end{array}$ & 2.92 & .679 & 2.95 & .903 & -.03 \\
\hline $\begin{array}{c}\# 13: \text { To promote literacy } \\
\text { and reading... }\end{array}$ & 3.21 & .627 & 3.11 & .679 & .10 \\
\hline $\begin{array}{l}\text { \#14: Leadership in } \\
\text { information and } \\
\text { instructional } \\
\text { technologies }\end{array}$ & 2.85 & .714 & 2.79 & .889 & .06 \\
\hline $\begin{array}{l}\# 15: \text { Networks enhance } \\
\text { access }\end{array}$ & 2.35 & .838 & 2.48 & .894 & -.13 \\
\hline
\end{tabular}

Average Means Total

2.84

2.83

\section{School Culture and the Library Media Program}

Question 20 asked: "What elements in your school environment help or hinder full implementation of the mission of Information Power in your program?" The respondents identified characteristics that were coded into either positive or negative factors and then rank-ordered. Respondents who offered positive elements claimed that their programs were enhanced by the following factors:

1. use, respect, and support of the library media program by teachers, principals, and administration;

2. a program that promotes the reading habit and integrates information skills with the curriculum;

3. an enthusiastic proactive library media specialist who encourages use. 
Other positive factors cited were a good facility, good public relations, and supportive library staff and parents.

On the other hand, respondents who offered negative elements claimed that their programs were hindered by the following factors:

1. Budget constraints, especially lack of money for technology;

2. Lack of a flexible schedule prohibiting planning time with teachers;

3. Lack of commitment, use, and support from teachers who are reluctant to change;

4. Inadequate or small facility with inadequate resources;

5. Lack of vision and support from administration.

Other negative factors cited were lack of support staff, lack of a unified media center; lack of continuity because the library media specialist is transient, lack of public relations to gain community support for programs.

\section{RECOMMENDATIONS AND FUTURE IMPLICATIONS}

Although education reform remains a national political issue since the publication of $\mathrm{A}$ Nation at Risk (NCEE, 1983) and the national legislation of Goals 2000, the past decade has seen little systemic change. Educational reform movements, however, have given rise to ambitious programs for the development of national standards in subject areas, but most of these efforts have foundered at the national level (Gagnon, 1996).

Greater hope for substantive change may lie in specific state initiatives and local efforts. Here, too, the record is disappointing. All of the New England state educational media associations have created standards or learning goals for school library media programs during the 1990s, but these efforts have not been translated into meaningful state standards. Without states requiring implementation of standards including full-time library media specialists and flexible schedules, library media specialist are left to negotiate change in their own schools. The major stumbling block for elementary library media specialists was that "specialists" are assigned to cover classes for the contractual unassigned time for elementary teachers. Thus, professionals in this study encountered limited success in negotiating change. Their problems seem doubly significant because they are a biased sample of good library media specialists anxious to create effective programs. As cooperating media specialists and mentors for student interns, they are a self-selected group providing positive role models. These individuals and their programs are well above average for the New England region; yet, their success in implementing Information Power has been limited. With fifty-eight percent of these library media specialists admitting that implementation of Information Power is only somewhat or not realizable, what are the implications for others? Perhaps, it is time for the profession to establish national standards that are endorsed by states as benchmarks for achievement of information literacy for all students.

Library media specialists and their professional associations need partnerships, however, in order to establish these standards at all levels: national, regional, state and local. It is time to stop talking to ourselves and to stop making unrealistic demands on individuals, but instead use the political process to gain support for the proposed AASL and AECT National Standards for Information Literacy by connecting them to Goals 2000 and other national standard movements. While AASL and AECT are currently working to develop new standards in information literacy, they should continue to seek additional partners to endorse and implement these standards across all disciplines. Support is needed from a broad base of educational groups such as: the national teachers' unions, administrators, associations for curriculum development, national standards groups, national associations for school committees, and parent advisory groups. At the same time, regional and state associations need help to translate the proposed national standards into mandated state standards by gaining support from state legislatures, state departments of education, and state education boards.

These groups represent our fellow stakeholders in a shared enterprise of education-where library media programs and schools can become learning-centered and where students are achieving information literacy skills. While recognizing that all stakeholders are committed to education and to the idea that all children can learn, we must also recognize our cultural differences. Each group has a unique constituency, language, and culture focused on their philosophical and political beliefs, expectations, and habitual approaches to ensuring good education for all children. As we work to 
ensure all children have equal access to a variety of information resources and to information literacy skills, we also need to acknowledge and understand the cultures and vocabularies of our potential allies. We need to persuade stakeholders to accept our goals and standards by demonstrating persuasively that we can help them realize their goals, and in so doing ensure that all children learn to use information and ideas effectively. Furthermore, our new vision needs to offer not only information literacy standards, but also a framework for teaching and assessing them. We must be accountable for our library media programs and for student achievement of information literacy skills if our library media programs are going to survive and thrive in the twenty-first century.

\section{REFERENCES}

American Association of School Librarians and Association for Educational Communications and Technology. (1988).Information power: Guidelines for school library media programs. Chicago: American Library Association.

American education: Still separate, still unequal [Special issue]. (1995). Daedalus: Journal of the American Academy of Arts and Sciences, 124(4).

DeCandido, G. A., \& Mahoney, A. P. (1992). Overworked and under budgeted: Staff and funds for school library media centers. School Library Journal, 38(6), 25-29.

Eaton, G. \& McCarthy, C. A. (1995). The art of the possible: Integrating information skills and literature into the curriculum. Emergency Librarian, 23(1), 24-30.

Fiske, E. B. (1991). Smart schools, smart kids: Why do some schools work? New York: Simon \& Schuster.

Gagnon, P. (1995, December). What should children learn? The Atlantic Monthly, 276(6), 65-78.

Giorgis, C. \& Peterson, B. (1996). Teachers and librarians collaborate to create a community of learners. Language Arts, 73(7), 477-482.

Grover, R. \& Fowler, S. G. (1993). Recent trends in school library media research. School Library Media Quarterly, 21(4), 241-247.

Haycock, K. (1992). What works: Research about teaching and learning through the school's library resource center. Seattle: Rockland Press.

Lance, K. C. (1993). The impact of school library media centers on academic achievement. Castle Rock, CO: Hi Willow Research \& Publishing: Colorado Department of Education.

McCarthy, C. A. (1993). A big engine that might: The School Library Media Act. American Libraries, 24(9), 877-880.

Mellon, C. (1990). Naturalistic inquiry for library science: Methods and applications for research, evaluation, and teaching. Westport, CT: Greenwood Press.

National Commission on Excellence in Education (NCEE). (1983). A nation at risk: The imperative for educational reform: A report to the Nation and the Secretary of Education, U.S. Department of Education.. Washington, DC: The Commission: (Superintendent of Documents, US G.P.O. distributor)

Neuman, D. (1989). Computer-based education for learning disabled students: Teachers' perceptions and behaviors. Journal of Special Education Technology, 9(3), 156-166.

Oberg, D. (1990). The school library program and the culture of the school. Emergency Librarian, 18(1), 9-16.

Putnam, E. (1996). The instructional consultant role of the elementary school library media specialist and the effects of program scheduling on its practice. School Library Media Quarterly, 25(1), 43-48.

Shannon, D. M. (1996). Education reform and school library media programs: Perceptions of Kentucky’s school library media leaders. School Library Media Quarterly, 25(1), 35-41.

Sizer, T. R. (1992). Horace's compromise: Redesigning the American high school. Boston: Houghton Mifflin.

Sizer, T. R. (1996). Horace's hope: What works for the American high school. Boston: Houghton Mifflin. 


\section{$\boldsymbol{\Delta}$}

Smith, T. M. (1995). High school students ten years after "A nation at risk": Findings from the condition of education 1994. Washington, D.C.: U.S. Department of Education, Office of Educational Research and Improvement.

Spindler, G. (Ed.) (1982). Doing the ethnography of schooling: Educational anthropology in action. New York: Holt, Rinehart, \& Winston.

Stripling, B. K. (1996). President's Message: Learning-centered libraries--A vision for the future. AASL Hotline/Connection, 4(1), 1.

White, H. D. (1990). School library collections and services: Ranking the states. School Library Media Quarterly, 19(1), 13-26. 
To:

School:
From: Dr. Cheryl A. McCarthy

URI, GSLIS, Kingston, RI 02881

\section{The Challenges of Implementing Information Power: National Guidelines for School Library Media Programs - a Survey}

\section{Would you please answer the following questions about your school?}

1. Number of students at this school: of faculty: Number of library media specialists (FTE): Number of library clerks/support staff (FTE) Number of volunteers:

2. What is the size of your collection of books? Materials: Computers: Computer software: periodicals: Audio Visual

3. What is the average age of your collection? Pre-1970's $70 \mathrm{~s}$ '80s ‘90s

4. Annual print budget Annual supply budget

Annual AV budget Annual budget for technology

5. Number of items purchased in the past 12 months: Books: Audio-visual materials: (specify) Computers: Periodical subscriptions:

How many: Total number of students:

6. Do you cover other schools? Number of other library media specialists (FTE: Computer software: Number of faculty: library clerks/support staff (FTE):

Information Power requires three factors that must be present to achieve the national mission. To what extent does you school support these factors?

1. Full integration of the library media program into the curriculum.
a. not yet b. somewhat
c. _____ frequently $\mathrm{d}$. fully

2. A partnership among the library media specialist, district level personnel, administrators, teachers, and parents.
a. not yet $b$
somewhat
c. frequently
d. fully

3. The serious commitment of each of those partners to the value of universal and unrestricted access to information and ideas.
a. not yet $b$. somewhat
c. frequently
d. fully

\section{To what extent are you able to meet the following seven objectives?}

4. To provide intellectual access to information through systematic learning activities.

a. not yet $b$ somewhat c. frequently $\mathrm{d}$. fully

5. To provide physical access to information through a carefully selected and systematically organized collection.

a. not yet $b$. somewhat c.

c. _____ frequently $\mathrm{d}$. fully 
6. To provide learning experiences that encourage users to become discriminating consumers and skilled creators of information.
a. not yet $b$ somewhat
c. frequently $\mathrm{d}$. fully

7. To provide leadership, instruction, and consulting assistance in the use of instructional and information technology.
a. not yet $b$ somewhat c. frequently
d. fully

8. To provide resources and activities that contribute to lifelong learning.

a. not yet $b$ somewhat c. frequently d. fully

9. To provide a facility that functions as the information center of the school. a. not yet b. somewhat c. frequently $\mathrm{d}$. fully

10 To provide resources and learning activities that represent a diversity of experiences, opinions, social and cultural perspectives.

a. not yet b. somewhat c. frequently

d. fully

\section{Information Power identifies five challenges to fulfill the mission. To what extent are you able to meet these challenges?}

11. To provide intellectual and physical access to information and ideas for a diverse population whose needs are changing rapidly. not yet b. somewhat c. frequently $\mathrm{d}$. fully

12. To ensure equity and freedom of access to information and ideas, unimpeded by social, cultural, economic, geographic, or technological constraints.

a. not yet $b$. somewhat c. frequently $\mathrm{d}$. fully

13. To promote literacy and the enjoyment of reading, viewing, and listening for young people at all ages and stages of development.

a. not yet $b$. somewhat c. frequently $\mathrm{d}$. fully

14. To provide leadership and expertise in the use of information and instructional technologies.

a. not yet $b$ somewhat $c$. frequently $\mathrm{c}$ fully

15. To participate in networks that enhance access to resources located outside the school.

a. not yet $b$ somewhat c. frequently $\mathrm{d}$ fully.

16. Do you believe that the mission, objective, and challenges of Information Power are realizable at your school? Why or why not? 
17. Does you library media program have an open and flexible schedule? Please describe your schedule, program, and use of the library center.

18. How is the use of the library media program influenced by the attitudes and expectations of teachers, administrators, and children toward libraries, reading, and learning?

19. What instructional technologies do you have in the library media center and how are they used by you, teachers, administrators, and children? Do you have an automated system, circulation and catalog?

20. What elements in your school environment help or hinder full implementation of the mission of Information Power in you program?

Pleas use the reverse of this sheet if necessary. Thank you. 